\title{
ACADEMIC FREEDOM IN THE UNITED KINGDOM
}

\author{
LORD CHORLEY*
}

INTRODUCTION

This article is concerned with academic freedom in the United Kingdom, particularly in the universities. On the narrow front of court decisions there is very little to be said on the subject, nor has much systematic attention been given to it on a political, sociological, or even educational basis. ${ }^{1}$ Academic freedom is indeed taken for granted in the United Kingdom, and matters taken for granted are not much written about in a systematic way. In regard to this particular subject, this is no doubt a pity. On the other hand, there are several matters which are very much bound up with academic freedom which have been receiving a good deal of attention in recent years, especially in the universities. Some of these certainly have legal aspects which are of substantial importance and which would repay a more careful analysis than $I$ am in a position to make here. The following pages are indeed offered tentatively and with some diffidence as prolegomena to a more substantial study which it is to be hoped that one of our constitutional lawyers may one day be induced to undertake.

What is entailed in the expression academic freedom? This problem is studied in other pages of this symposium. For the purpose of this article it is sufficient to say that it means freedom of thought, utterance, teaching, and research in academic institutions; and the extent to which this in fact exists in the United Kingdom it will be my principal object to discuss. It may be said at once that freedom of thought and utterance is one of the most prized civil liberties of the Englishman, and the teachers in the universities are no less free in this regard than their fellow citizens. It is hardly necessary here to add that this principle is qualified by the general obligation not to overstep the limits set by the general law, particularly in respect of defamation.

CiviL Liberties-Recent Trends in the United Kingdom

This last statement is no doubt a commonplace, but the position in England as regards liberty is constitutionally very different from that which exists in the United States of America, resulting in a difference of atmosphere which will be very relevant in the following discussion. It may accordingly be useful to remind ourselves at the outset that in England freedom, though no doubt just as real, is much more intangible than in the United States. This is because we have no formal guarantees

- M.A. 192r, Oxford University. Queen's Counsel, rg6r. Honorary General Secretary, Association of University Teachers. Formerly Cassel Professor, London University.

${ }^{1}$ It is hardly necessary to draw attention to the contrasting position in the United States of America. 
of liberty in our Constitution. It is seldom possible for a litigant in an English court to found his case upon a principle of liberty, as it is in the United States; he has to find some rule of the common law on which to rely. In the United States the conception of liberty as validated in the Constitution has given rise to a great jurisprudence. In England though civil liberty is an expression in constant use, more perhaps among the politically-minded than among lawyers, the number of reported cases in which our civil liberties have been directly in issue is not large. And the judicial pronouncements in such cases, particularly perhaps in modern times, tend to be much narrower and less directly preoccupied with liberty than those of American judges. It is uncommon to find in the English reports those eloquent statements of principle which give the American cases on this subject a flavor all of their own.

So far from formulating in their judgment broad conceptions of libertarian principle, English judges have tended to handle each point as it arose, often in a narrow context of precedent, and from time to time in a mood which can only be described as reactionary. ${ }^{2}$

None of the great constitutional documents of the past, such as Magna Carta, the Petition of Right, the Habeas Corpus Act, or the Bill of Rights enunciates a broad doctrine of liberty as does the Declaration of Independence, though English politicians and English judges have made use of them to good effect. Such modern statutes as have been concerned with problems of freedom have tended to be in breach of this great tradition. ${ }^{3}$

However, the last impression which I wish to convey is that there has been a notable decline in freedom in England. There are certainly prophets of gloom, and it may be that the general satisfaction of the average Englishman with the existing position is a source of danger. Certainly I think that the legal profession as a whole has been much too insensitive to the nibblings on the periphery of freedom to which I have referred above. ${ }^{4}$ Large sections of the population, however, can be relied

\footnotetext{
2 'This is obviously not the place to produce an analysis of the recent English cases affecting civil liberties. A few citations may, however, be useful to readers who would like to pursue the matter further, as Duncan v. Jones, [1936] I K.B. 218 (right of the police to stop a public mecting on reasonable apprehension of breach of the peace); Thomas v. Sawkins, [1935] 2 K.B. 249 (right of police to attend public meeting held on private premises); Elias v. Pasmore, [1934] 2 K.B. $16_{4}$ (papers illegally seized by the police may nevertheless be used in evidence on a criminal prosecution); Liversidge v. Anderson, [1942] A.C. 206 (lack of jurisdiction of High Court to inquire into adequacy of decision of executive to imprison a citizen under a wartime regulation-this case is mainly noteworthy for the dissenting speech of Lord Atkin which provides a notable exception to what has been said above about the failure of modern English judges to deal with freedom points in the grand manner); $R . v$. Caunt, an unreported case which will be found in ARThur $L$. Armitage \& James W. C. Tunner, Cases on CrIMINAL LAw 387 (Ist ed. I958), in which a violently anti-semitic article in a newspaper was considered not to be seditious libel on the ground of freedom of speech! Christie v. Leachinsky, [1947] A.C. 573, which discusses whether, when an arrest is made, the reason for it must be given to the man detained.

${ }^{3}$ See, e.g., the Incitement to Disaffection Act of $1934,24 \& 25$ Geo. 5, c. 56, which raised a storm of protest in liberal quarters. The wartime legislation in both wars was naturally illiberal in character.

"It may be considered significant that the index to Halsbury's Laws of England, itself a substantial volume, contains under the title "liberty" only four entries. Two of these are concerned with religious freedom, one with a technical point, and the fourth deals with the subject in a general way, taking up only some two pages of text in the chapter on Constitutional Law.
} 
upon to rally to the standard of liberty, or indeed to raise it when necessary, and among these both politicians and newspapermen are, perhaps naturally, very prominent. " Nevertheless, it would over the years be true to say that English parliamentarians have handled problems of freedom empirically, in much the same way as have the judges. Statesmen, and politicians, as is their wont, discuss liberty in a more rhetorical and, sometimes, as with Burke or J. S. Mill, in a more philosophic manner than the judges, but by and large their approach has been similar.

Academic freedom falls into place in this general pattern. I am not aware of any case in which the phrase has been used by a judge. In Parliament it would no doubt be possible, by a more patient research than $\mathrm{I}$ am in a position to make, to find a number of debates in which problems of academic freedom have arisen indirectly if not directly.

\section{II}

\section{Pressures Inimical to Academic Freedom}

The above disquisition on the present position of civil liberties in England, which, short as it is, may be regarded by some readers as too long for an article on academic freedom, was induced by my earlier statement that the university teacher's position in regard to freedom of speech is just the same as that of any other citizen. But to cut short the analysis at this point would very properly be adjudged by the reader as a highly unrealistic treatment of the subject. We must have regard to the pressures, both tangible and intangible, which may be brought to bear upon the members of an academic institution so as to compel them, or at any rate to persuade them, to forego their freedom to teach and carry on the other activities of a university teacher, in accordance with their consciences. How far are English teachers ${ }^{\boldsymbol{\theta}}$ subjected to such pressures? As far as tangible pressures are concerned I think it is true to answer "not at all." Intangible pressures which may be political,

\footnotetext{
- Again this is not the place to document these assertions in detail, especially since Conservative politicians not in the past much identified with the cause of freedom have in recent times been building their own conception of liberty into their party programs so that the parties of the left no longer have a monopoly of the propaganda in this particular line. I will permit myself, however, to refer to three recent episodes which seem to me to be of significance-one of which, indeed, has a university context. In 1957 , there was a storm of protest over the tapping of telephone lines by the police in connection with a criminal case which led to a special inquiry into the subject by a Committee under the late Lord Birkett. Report of the Committee of Privy Councillors Appointed to Inquire Into the Interception of Communications, CMND. No. 283 (1957). As a result of their Report, there was a considerable modification in the permitted procedure. In 1957 a university teacher was approached by a member of the Security Service with a view to his reporting on the political leanings and activities of his colleagues. This move was strongly criticized in Parliament and the incident was for a time headline news in the press. See 203 H. L. DEB. (5th ser.) Ir22 (1957). Finally, during the very period when this article was in preparation (March-April Ig63) the decision of the Home Secretary to deport Chief Enahoro to Nigeria to stand his trial for treason moved not only the Opposition but a sufficiently numerous section of the Government Party to feel that civil liberty was being infringed, and caused serious concern to the Government; and this despite a decision of the High Court that such deportation would be fully in accordance with the law. See 675 H. C. Des. (5th ser.) 1287 (1963).

'I ought to make it clear that in general when I use the word English in this article my remarks 2pply to the United Kingdom.
} 
scientific, or social are more difficult to estimate; but the climate of opinion in our universities at any rate is so strongly on the side of academic freedom that social pressures which in some countries are thought to exert a contrary pull are here comparatively feeble. On balance I think it is safe to say that academic freedom is enjoyed as fully in English universities as anywhere else in the world. Nevertheless, some description or analysis of the pressures in question seems plainly to be called for.

Pressures may come from outside or from inside an institution; they may, of course, be of different kinds. Those which have in the past proved most inimical to academic freedom have been political and religious, ${ }^{7}$ they were usually of the direct type. Religious pressures were for a long time a more serious menace to academic freedom in English universities than were political; but for practical purposes they have ceased to be of importance. As will appear hereafter, it is not practical politics for a religious body to try to set up a university in England; nor under the accepted forms of statutes can our universities establish religious tests, either for entrance, in connection with the award of degrees, or in any other way. ${ }^{8} \mathrm{~A}$ typical example runs as follows,

it is a fundamental condition of the constitution of the University that no test of religious belief or profession shall be imposed on any person in order to entitle him or her to be admitted as a Member Professor Teacher or Student of the University or to hold office therein or to graduate thereat or to hold any advantage or privilege thereof. (Bristol).

The struggle for religious freedom in the universities was in England an outstanding feature of the middle years of the nineteenth century at Oxford and Cambridge. Although it was the religious conflict which attracted most attention in these historic universities, scarcely less significant was their hostility to the admission of women to full membership and privilege. The liberal influences which fought against religious tests were also favorable to the educational rights of women, and these, too, are now frequently guaranteed by charters of incorporation. ${ }^{0}$

In earlier times religious pressures may have been more dangerous than political pressures, but in the modern age there can be no doubt that the main enemy to academic freedom has been the all-powerful state. In most European countries the

'I have already referred to social pressures which I appreciate may in certain circumstances be of considerable importance. For the reason given $I$ do not estimate that they are a dangerous drag on academic freedom in England; a more detailed analysis of this point is beyond the scope of this article.

${ }^{8}$ It is significant of the importance which attached to religious pressures until towards the end of the nineteenth century that those responsible for initiating the new universitics of that century, many of whom belonged to nonconformist sects, invariably obtained a clause in the charter by which religious tests were excluded, and this despite the fact that in $187 \mathrm{I}$ a general act had been passed to remove religious disqualifications. Universities Tests Act, I87x, 34 \& 35 VICr. c. 26.

- Again the Charter of Bristol University provides a typical example of such a clause, as follows: "Women shall be eligible for any office in the University and for membership of any of its constituent bodies and all Degrees and Courses of Study in the University shall be open to women subject to such conditions and regulations as Statutes of the University may prescribe." Earlier Charters were not so liberal. However, the Sex Disqualification (Removal) Act, 19r9, 9 \& ro Geo. 5, c. 7r, enabled the older institutions to admit women. 
universities are state institutions and the professors and teachers are either civil servants or in the last resort can be subjected to state control. Until the rise of totalitarian regimes these unpleasant truths were largely masked by respect for tradition, and the decencies of civilized life, though political pressures were never far from the surface, particularly in Germany. And with the return to quasi-normality over much of Europe an uneasy academic freedom has been making a comeback of sorts. The underlying reality of state power is now, however, well understood, and in some countries its cramping effect is only too obvious.

\section{III}

\section{AUTONOMY OF BRITISH UNIVERSITIES}

In England, however, the universities have never been state institutions. Oxford and Cambridge were in origin religious institutions; and the Inns of Court, which in earlier times had much more the status of universities than they have now, were founded and controlled by the powerful legal profession. After the Reformation the Anglican Church became dominant in Oxford and Cambridge though a lay element assumed an increasing importance. It was, however, in connection with James II's attack on Cambridge and his attempts to build up Roman Catholicism at Oxford that the state came into clear conflict for the first time with the English university world. The struggle was not so much for academic freedom as for university independence.

The resistance of the fellows of Magdalen College became a symbol to the nation, and with the flight of the King the attack on the universities collapsed. This attempt by the Executive to interefere with the self-government of the universities and its final failure is an event of basic significance in the development of academic freedom in England. The independence of its universities is obviously the most important safeguard of academic freedom in any nation. During something like a century and a half after the defeat and flight of James II, Oxford and Cambridge continued to be the only universities in England. The leaders of the Whig oligarchy who by and large held power in the country during this period were often alumni of one or the other of the universities; and in the general current of eighteenth century politics no question was likely to arise, or in fact did arise, that was calculated to bring the institutional arrangements at the two universities, which are broadly similar, into national dispute. ${ }^{10}$

England began to make an entrance into the modern university world in the r830's, and then rather halfheartedly, with the setting up of university institutions in London in 1836 and at Durham in 1832 . It is important to notice that, although

\footnotetext{
${ }^{10}$ Oxford, of course, remained predominantly Tory, but this fact did not influence the position-the Tory dons appreciated their self-government as much as did their more Whiggish opposite numbers at Cambridge. Nor did the situation change as the Whigs began to lose their grip on the state in the later cighteenth century; by then the general position of independence at the universities had operated long enough to have become generally accepted. On the other hand, there were no doubt interferences over small matters at both universities, often at the personal initiative of the sovereign.
} 
the state gave its imprimatur to both these universities, it did not take any active part in their creation. The position was exactly the same when later in the century institutions of higher education began to develop in the great provincial cities. In all these cases the initiative and the finance were provided by voluntary organizations and even individuals. ${ }^{11}$ Successive governments were happy to stand by in a typically English way, and watch work being done, the essential nature of which in the national interest only became clear as time passed.

But those who created the new university institutions, even if they did not follow the institutional arrangements which had gradually been developed at Oxford and Cambridge, adhered to the view which was by this time axiomatic in these institutions that a university must be an independent self-governing institution. It would not have been easy for the State to have challenged this attitude; it was getting essential national work done for nothing, and in any case it was too late in the day. Indeed, I am not aware that there is any evidence that those in authority showed any inclination at any stage to switch to a continental model.

Quite apart from their readiness to grant a considerable measure of autonomy to the universities in connection with their self-government, successive governments have refused to be drawn in when demands were made, sometimes in the press and sometimes in Parliament, that something should be done to diminish the influence of the Communist Party in the field of education. To have given way to such clamor would clearly have involved a serious interference with the independence of the universities and with academic freedom..$^{12}$

In the result the constitutional documents of all our universities, whether charters, university statutes, or supporting Acts of Parliament, are directed to establishing autonomous self-governing institutions. The fact that in these constitutions provision is always made for a substantial, indeed often a numerically preponderant, representation of the outside interest on the governing authority of the university ${ }^{13}$ does not logically cut down its independence.

${ }^{11}$ Some slight qualification on this statement is perhaps called for, since the Church of England was involved at Durham and at King's College, London. Even so, it was individuals within the Church who were active, rather than the Church as a national institution.

12 There are in fact Communists among the teachers at a number of our universities, some of them of high academic distinction. Their number is invariably only a minute fraction of the whole tcaching staff; but on occasion there have been enough of them employed in one institution to form a small group, and this has led to attacks in the press and in Parliament. A typical example of such an incident was the attack made by the late Lord Vansittart on what he described as the "Communist clique" in the University of Birmingham. See r66 H. L. DEB. (5th ser.) 6I3 (1950).

${ }^{13} \mathrm{By}$ outside interest I mean bodies or individuals not engaged in the day-to-day work of the institution. At the time when the initiative in the foundation of institutions of higher education was being taken by local authorities, chambers of trade, businessmen, industrialists, and others, it was natural that these organizations and people should have provided for themselves a continuing interest in the government of the institution. Although this question is not free from controversy, it is safe to say that the general view is that the contribution of these "outsiders" to the work of the universities has been valuable. The University Grants Committee (as to which see infra at 655-59), which is the nearest approach we have to a central policy-formulating authority, certainly attaches importance to the presence of outside persons of influence upon the governing authorities of universitics, and before advising the Government to sanction the setting up of a new university in any particular locality will 
So much is this so that I think it could well be agreed that it is a convention of the British constitution that in establishing a new university the Executive is under the obligation to ensure that it has complete freedom of self-government. Certainly there is nothing that British universities prize more than their independence and freedom from political dictation. ${ }^{14}$

What has just been said involves the important point that no university can be set up in the United Kingdom without the approval of, and affirmative action by, the State. The fact, which I have underlined more than once in this article, that the initiative in the creation and development of the modern, so called Redbrick, universities in England came from local authorities, other organizations, and individuals does not mean that private universities can be set up here as they can be, and are, created in the United States. ${ }^{15}$ Other institutions of higher education can be and are set up and these may award their own distinctions; but degree-conferring powers can only be granted by royal charter or by statute and will normally only be granted to universities, where it is stated that "the power to confer degrees is a necessary attribute of a university." 16 Of recent years universities have been established in the United Kingdom by royal charter, by statute, and by charter confirmed and amplified by statute. ${ }^{17}$ Whether or not a particular institution is, or is not, a university appears to be a question of law. ${ }^{18}$

In the result all the universities created in the United Kingdom during the past hundred years have been fully public in character; and it is conceived that an application for a charter by, say, a denominational religious body such as the Roman

always require to be satisfied that local citizens of infuence in the community are ready to give practical support, or play their part in the affairs of the new institution. The Association of University Teachers while acknowledging the valuable contribution which these outside interests have made, and can make, has expressed the view that they tend to obtain too much weight on governing bodies, at any rate numerically. These expressions of opinion seem to have had some effect, as in the most recent charters and statutes the numerical preponderance of outsiders has been substantially reduced. It is fair to say that when the numerical weight has been used against the opinions of the academic members of the Council or other organ of authority it has always been in respect to matters of practical business, particularly of finance. There is no evidence of any interference in purely academic matters, or of any curtailment of freedom on the part of these members.

14 An instructive illustration of this point arose a few years ago in connection with the superannuation arrangements for university teachers. These are at present based on a system of life insurance policies over which the individual universities retain a substantial amount of control. A proposal was made to abandon this system in favor of a formal pension scheme based on length of service and final salary at the time of retirement-the sort of arrangement which in fact exists in the civil service. The opposition to this scheme in the universities was to a considerable extent based on the argument that it involved an interference with autonomy. The suggestion was in fact rejected.

${ }^{15}$ Some years ago a proposal was in fact put forward for the establishment of a private type university in England. This project in fact came to nothing. I believe that it was intimated to the promoters that their proposal was not constitutional, and that if they persisted with it action would be taken against them in the courts. It may have been this fact which caused them to desist.

${ }^{10}$ See I3 Halsbury's Laws of ENGLaNd $\$$ I441-43 (3d ed. I952).

${ }^{17}$ Ibid.

${ }^{18}$ See St. David's College, Lampeter v. Ministry of Education, [I95I] I All E.R. 559 (Ch.). This seems to be the first and only case in which the attributes of a university have been discussed in an English court of law. The college was suing for a declaration that it was a university, a status which it has since achieved. The judge ruled against it, holding, inter alia, that the right to grant degrees which was conferred by its charter did not of itself constitute the college a university. 
Catholics or Wesleyans, who have established universities in the United States and Canada, would fail. Most English university teachers would regard the creation of a denominational university as an infraction of academic freedom. ${ }^{19}$

IV

\section{Indirect State Pressures}

The cynic may contend that what has gone before presents a mere surface of academic freedom. He will demand to know whether under that surface the government departments and great business organizations which now contribute much the greatest part of British university finances are really content to provide every year sums of money running into tens of millions of pounds, ${ }^{20}$ without insisting that they shall call the tune. And he may insist that, whatever has been the uneasy position during these first postwar years, the vastly increasing requirements of the State for skilled personnel which only the universities can educate, and the colossally increased resources from the State which will obviously shortly be called for, must inevitably in the not distant future lead to full governmental control of the universities. What sort of a dam can the rather feeble institutional safeguards above described provide against this authoritarian flood?

I shall examine in a moment these less direct pressures on the independence of our universities. All that can be said in general answer to the charge is that so far the weak dams have held with a firmness which would be surprising to all who did not know the strength of tradition in England. Although we miss the support of the legal framework which the constitution of the United States and its present liberal interpretation by the Supreme Court provide, both the tradition in the universities and the existing public opinion in favor of academic freedom are perhaps stronger here than there.

As to the future, while recognizing the all too obvious dangers, we can only face it with that optimism which successful achievements in the past entitle us to entertain and which, after all, is one of the characteristics that helps the English to work through the difficulties which have been a fairly constant feature of their history.

The pressure which calls for the most attention, and which has of recent years caused most concern among those sensitive for the freedom of the universities, is undoubtedly that just mentioned-that is, the rapidly increasing financial dominance of the State. In addition, however, I propose to discuss the rather similar problem

\footnotetext{
${ }^{10}$ In the mid-nineteenth century there was a considerable controversy over the establishment of a National University in Ireland. The British Government gave way over this, and it is not too much to say that the institution became, in fact, Roman Catholic. It is now, of course, entirely outside the United Kingdom.

${ }^{20}$ The recurrent grant which roughly provides for salaries and upkeep is now running at some 650 million per annum and is expected to rise to $\$ 76$ million by 1966 . The non-securrent grant, which in effect means the cost of new buildings, was planned in 1962 at $\ell_{6}$ 100-110 million for the following four years-enough as the Chief Secretary of the Treasury said in a graphic phrase "to build two ncw towns each with a population of 50,000 ."
} 
which arises from the very large and continually increasing subsidies for scientific research which come to the universities from industrial and commercial sources.

\section{V}

\section{State Finance and the University Grants Committee}

Until after the first world war British universities managed to keep their heads above water without more than nominal financial assistance from the State; their fee incomes were substantial and the older ones had large endowments. The depreciation of the currency which came with that war reduced endowment incomes appreciably, and it soon became evident that the universities could no longer pay their way from their own resources.

The government by this time was not unwilling to help, and gave indications to this effect. But the subordination of the German universities to the State had become only too evident during the war, and university dons were familiar with the line timeo Danaos et dona ferentes. If they were to receive help through the Board of Education, a political department of the State, their autonomy would be lost. ${ }^{21}$ A typical British compromise was worked out by which the grants-in-aid were to be paid directly by the Treasury-civil servants also, but without any knowledge of education! They would require, therefore, to be advised as to the needs by outside experts. A new organization composed largely of prominent university people was therefore set up; it was called the University Grants Committee. This was in fact established in I9I9, and the subsequent history of the universities in the United Kingdom has to a substantial extent turned upon its work, particularly in the years since the end of the second world war. ${ }^{22}$ It is difficult to realize that at the time of its creation the Grants Committee was advising the Treasury on the basis of an expenditure of some one million pounds per annum. The current figure, running at more than one hundred million pounds per annum, serves to underline both the vast increase of the work done by the Committee and the massive character of the State's financial stake in the work of the universities.

It is naturally not my object in this article to attempt a general assessment of the work of the University Grants Committee, but it is obviously necessary to attempt an analysis of its impact upon the independence of the British universities. This is not easy as there have from the beginning been very varying opinions upon the subject among those prominent in the work of the universities. Thus, at the very beginning Professor Ridgeway of Cambridge, typical of Conservative opinion, considered that the establishment of the Committee and the acceptance of aid by the

\footnotetext{
${ }^{21}$ The small grants that had in fact been made in the pre-war years had gone for the most part through the Board, which had already set up an advisory committee of its own in Igrr. The whole history of the modern development of grants-in-aid to the universities is admirably described in ROBERT O. Berdahi, Brmtish UntverstTIES AND the State (1959).

${ }^{22}$ For a full and valuable history of the University Grants Committee, see Berdart, op. cit. supra note $2 \mathrm{r}$, at $48-93$.
} 
universities from the State was "fraught with the gravest danger" to their independence. ${ }^{23}$

Fears of this kind were no doubt prevalent, particularly at Oxford and Cambridge. Yet there can be little doubt that the Government was genuinely anxious to establish a system which would safeguard the independence of the universities and obviate the necessity for a new and difficult area of activity for the civil service. In this connection, a Treasury minute to the Parliamentary Accounts Committee, though of a later date, provides a significant indication of the policy maintained throughout by that Department. The minute stated that certain proposals of the Committee "would involve difficulties affecting the academic freedom of the universities. ... I It had never been the policy of any government that the universities should be subject to statutory regulation or that academic policy should be controlled by the State."24 And there can be little doubt that this statement reflects the view of successive Chancellors of the Exchequer. ${ }^{25}$

There is also a good deal of evidence that these views were genuinely held and were not just the pious platitudes of politicians, often more honored in the breach than the observance. To analyze this in detail would be out of place here, but two significant items may be referred to.

The first is the fact that, although the secretary of the Committee has always been a Treasury Official selected for this duty, the Chairman has been invariably chosen from the staffs of the universities, and the personnel of the Committee itself has from the beginning been predominantly academic. In so far as it has been reinforced by appointments from other walks of life, this has been for the specific object of strengthening it in respect of some particular aspect of its work, such as the consideration of salary scales for academic staff, or the giving of expert advice on building programs.

Of even greater importance in this connection is the fact that the Treasury has invariably supported the desire of the universities to be free of any outside audit of their accounts, and in particular not to be subjected to the powerful scrutinies of those important pieces of Parliamentary machinery, the Select Committee on Estimates and the Parliamentary Accounts Committee.

From the very beginning, that is in 1918 , the representatives of the universities, when discussing with the Government the whole problem of grants-in-aid to the universities, indicated their unwillingness to accept ordinary government controls, and particularly any governmental scheme of audit. In an address to the Third Congress of the Universities of the British Empire, Sir Alfred Hopkinson K.C., who had been Vice Chancellor of the University of Manchester, and had been closely

${ }^{23} 1 d$. at $6 \mathrm{I} \mathrm{n} .40$.

24 Id. at 120 .

${ }^{25} \mathrm{I}$ once heard Mr. R. A. B. Butler express himself in very similar terms to a deputation of Members of Parliament when he was Chancellor of the Exchequer. 
associated with these negotiations, described the university attitude quite bluntly in the phrase "there must be absolutely no control."26

In the result, the financial assistance afforded by the State to the universities was made in the form of block grants, not earmarked grants-the allocation being left to the Grants Committee, and no examination of the way the money was actually spent being afterwards conducted by or on behalf of the Treasury. ${ }^{27}$

Although the Government and the Treasury might be happy to create and indorse such an independent system it did not pass uncriticized in Parliament. The House of Commons has always been jealous of its power over the purse and has not only claimed the sole right to vote taxes, but also has insisted upon its right to scrutinize expenditure by the Government in order that its members may be satisfied that the money voted has in fact been spent in the way the executive had proposed when asking that the taxes be voted. It was for the purpose of making this right effective that the Select Committee on Estimates and the Parliamentary Accounts Committee were set up.

Although there have been, and are, exceptions to this system of control and scrutiny, the House of Commons has been very jealous of them, and generally has not allowed them to continue for long. The system of grants-in-aid to the universities is much the most important exception to the general rule; and, in making it free of the usual control, the Treasury must have realized that sooner or later voices would be raised in the House of Commons demanding that these grants should be brought within the general system.

It is indeed rather surprising that no real move was made to this end until 1951. By then, it was becoming evident that here there was a substantial and growing element in the national expenditure which was out of Parliamentary control. In its Report to the House of Commons for $195^{1-52}$ the Select Committee on Estimates proposed that the books and accounts of the universities should be open to inspections by the Comptroller General. This was followed up by the Parliamentary Account Committee in the two succeeding years with critical comments on the lack of information on this important field of expenditure. In its Report to the House of Commons for 195354 the Accounts Committee went further and said that at any rate in respect of the non-recurrent grants the Comptroller should be given access to the books of the Grants Committee. This was resisted by the Grants Committee, whose Chairman said it would be a serious breach of the accepted principle of the independence of the universities. It was also resisted by the Treasury on the same grounds.

This pressure from these two powerful committees of the House of Commons was clearly a serious matter, and the Treasury evidently felt that something more

\footnotetext{
${ }^{20}$ Also as a member of Parliament for many years he was well acquainted with the usual methods of Parliamentary control. BERDAFI, op. cit. supra note 21 , at 57.

${ }^{37}$ It should, however, be noted that owing to immediate postwar difficulties the grants were for a short period earmarked, viz., from 1947-1952.
} 
than a mere stonewalling policy was called for. A Committee under Sir George Gater, a retired civil servant of great eminence with a long experience of educational problems, was appointed to report on the problems of the administration of the nonrecurrent grants.

The Gater Committee reported in $1956^{28}$ in a reassuring way, though it made certain recommendations for improvements in methods. Notwithstanding this the Parliamentary Accounts Committee returned to the charge and in its Report for I955-56 strongly reiterated its demand of the previous year. ${ }^{20}$ Meanwhile the Grants Committee was strongly impressing on the universities the great importance of complying with the Gater Committee's recommendations; and the replies of the universities in $195^{6}$ satisfied the Grants Committee that they were either already doing so, or taking steps to that end. ${ }^{30}$

This information seems to have mollified the Accounts Committee, for the time being at any rate, since it has not repeated its demand. However, in order to forestall further demarches from that quarter the Grants Committee in 1959 instituted a further inquiry under Sir Arthur Rucker, another retired civil servant with long Treasury experience, to examine and advise how far the procedures recommended by the Gater Committee were in fact being observed by the universities. The Rucker Report ( 1960 ) was also satisfactory, though it made further recommendations. $^{31}$ This action on the part of the Grants Committee elicited a favorable reaction from the Accounts Committee.

Here the matter rests, at any rate for the time being. There are those who regard these events as a real interference with the autonomy of the Universities. It is important, however, to appreciate that at the end of the first round at any rate neither the universities nor the Grants Committee are producing their books of account for inspection; and most people seem to take the view that the general result of these exercises has been salutary in that it has led to a tightening up of the procedures in the universities for ensuring that these very large sums of money are properly spent. If interference goes no further, it can hardly be regarded as very objectionable.

What could perhaps be contended with rather better justification is that these events are symptomatic of the establishment of the power of the Grants Committee itself, and that this is resulting in an eroding of the independence of the universities, which is more serious than anything that has happened in the past. It is not at all easy to judge the validity of this assessment. The administration of the large non-recurrent grants, and even of the recurrent grants, on which many new develop-

${ }^{28}$ Methods Used by Universities of Contracting and of Recording and Controlling Expenditure, Report, CMnd. No. 9 (1956).

${ }^{90}$ For a more detailed account of these events, see Berdarn, op. cit. supra note 2r, at 127-32 passim.

${ }^{30}$ See the Introduction by Sir Keith Murray, Chairman of the Committee, in' Non-Recurrent Grants -Notes on Procedure 2 ( 1963 ).

${ }^{81}$ Id. at 3. Grants to Universities, Methods Used by Universities of Contracting and of Recording and Controlling Expenditure, Report, CMND. No. 1235 (rg60). 
ments in the universities depend, has undoubtedly led to the establishment of a number of uniform procedures, and to the giving of a good deal of advice by the Grants Committee to the universities, sometimes fairly strong in character. These matters to the sensitive smack of interference, though the Grants Committee maintains that it is acting as a partner with the universities in the great enterprise of higher education. In view of its predominantly university composition it is fair to say that, in so far as the work of the Grants Committee amounts to an interference with the autonomy of the universities, it comes from within and not from without the system. Moreover, it may also be pointed out that the growth in the authority of the Grants Committee has been parallelled by a no less important development in the power of the Committee of Vice Chancellors and Principals since the end of the last war. ${ }^{32}$

From what has been said above it will have become clear that grants in aid from the State to the universities have been increasing rapidly. Moreover, this is a process which is likely to increase almost in geometrical progression until towards the end of the century. There has long been a feeling among knowledgeable people in England that the proportion of schoolboys proceeding to the universities is much too low. ${ }^{33}$ Since the end of the war this view has become much more generally held, and there has been a remarkable increase in interest in higher education among the people as a whole. In 1939 the number of students in British universities was some 40,000 . It had already increased in 1962 to over Iro,000. The Government's proposals provide for a further increase of some 40,000 within the next five years; but in many quarters this target is regarded as much too low. Both the Labor Party which may well provide the next government and the Liberal Opposition have underwritten schemes of a much more ambitious nature, and there is a widespread belief that the target should and will be put up to at least 200,000 by the end of this decade. $^{34}$

These ambitious plans have been the work rather of politicians than of the university authorities or even of the academic staffs. ${ }^{35}$ Many both inside and outside the

\footnotetext{
${ }^{38}$ The Vice Chancellors are the executive heads of the universities, and the Principals of University Colleges, of which there are none in existence in England as opposed to Wales at the present time. They meet, in theory informally, in Committee at least monthly to discuss matters of common interest to the universities; and although, again in theory, they have no executive function, and cannot bind the autonomous universities, they do in practice formulate policies which are followed by the university administrations, and are thus of importance. Consultations between this Committee and the Grants Committee on matters of mutual interest are going on all the time.

${ }^{28}$ It has been decidedly lower in England than in Scotland and Wales, and indeed than in most of the more advanced European countries, though the precise extent of this is a matter of controversy.

${ }^{34}$ The need for a figure much higher than that officially proposed was argued some years ago by the Crowther Committee on Education, Report of the Central Advisory Council for Education $\times 5$ - 8 (r959); and it is commonly said that it had a figure like 200,000 in mind. Indeed, the Chairman, Sir Geoffrey Crowther, has since said as much on more than one public occasion. As to the Labor Party's program, see the Report of the Taylor Committee, The Years of Crisss: Report of the Labour Party's Study Group on Higher Education (1963).

${ }^{35}$ It should be noticed, however, that the Association of University Teachers (A.U.T.) has formally
} 
universities, however, regard these policies for what they call "indiscriminate expansion" as ill-advised, and as a serious threat to "the autonomy of academic institutions." 36 They consider that it is betraying the ideal of scholarship and the tradition of the British university to use these institutions for "the furtherance of an extrinsic social programme."

Many, possibly the majority of, university teachers in England regard this as too narrow an attitude, and would be prepared to take some risks in order that all children capable of benefiting by a university education should be entitled to receive one. They would argue that there is no better guarantee of academic freedom than the existence of a large highly-educated element in the population. All that it is legitimate to do here is to mention the two points of view, and perhaps to state my own preference for the more optimistic attitude.

\section{VI}

\section{Pressure from Business Interests}

The second topic for discussion under the head of indirect pressures is concerned with financial support to the scientific and technological departments of the universities, ${ }^{37}$ a matter which has been very much more under discussion in the United States than in the United Kingdom. ${ }^{38}$

It seems clear from the researches of Dr. Coslett that something like half the funds available for scientific and technological research in the universities of the United Kingdom are provided directly for this purpose either by government scientific organizations like the Department of Scientific and Industrial Research, or by private industrial organizations. The proportions of the subvention supplied by these two sources varies somewhat from time to time. Some time ago the industrialists were the preponderant givers, but of late years government sources have been in the ascendant. However, this present preponderance is believed to be largely due to military considerations. Apart from this the assistance coming from industrial sources would be substantially the larger and in any case is in absolute figures a continually growing amount. A good deal of this work is carried out in close

adopted a figure higher than that proposed by the Government, and that many university teachers are satisfied that the Crowther figure of 200,000 is attainable and ought to be aimed at. There is considerable difference of opinion among university teachers over this figure.

${ }^{36}$ See, e.g., the first leading article, True Ends, The Times (London), May 2, 1963, p. 13.

${ }^{87}$ It is believed that some social service departments have been similarly supported in connection with researches, but the material at my disposal does not permit me to do more than mention this ficld as one deserving of further inquiry.

${ }^{88}$ The only comprehensive study which we have in the United Kingdom, so far as I am aware, is that by Dr. V. E. Coslett, The Relations Between Scientific Research in the Universities and Industrial Research: A Report on Conditions in Great Britain, prepared for the Association of University Teachers in 1955 in connection with a general research initiated by the International Association of University Professors and Lecturers (I.A.U.P.L.). This was subsequently adopted and published by the I.A.U.P.L. in I955. 
cooperation with the Research Associations which are maintained by a number of the more important branches of British industry.

This aid from industrial sources is not largely applied to researches conducted purely in the interests of the donors. ${ }^{39}$ On the other hand, something like a third of the research projects going on at any one time in British universities will be to some material extent dependent on such assistance. Moreover, the projects in which industrialists are interested tend to absorb the time of senior scientists rather than juniors. ${ }^{40}$ Significantly also about one in five university scientists does consultative work for outside bodies, mostly for private industrial concerns.

It is exceedingly difficult to judge how far this imponderable pressure on the scientific and technological departments of British universities is a menace to academic freedom. It seems obvious that if all the money were provided without any strings attached, as indeed it is in respect of an appreciable proportion of the whole, the work would be likely to take a somewhat different slant, and might well pursue quite other directions. How far this would be in the deeper interests of scientific progress it is probably impossible even for the most knowledgeable to estimate with any degree of accuracy.

It can, I think, be said with confidence that there have been no cases where these industrial subsidies have been used to further ends which were solely in the interests of those who have provided them, or in which it has been claimed that the work undertaken had no scientific value in itself. Moreover, the university world in the United Kingdom is clearly very much alive to the possible dangers of the present situation as was made evident in a recent controversy at the University of Reading, where a chair has recently been established in the Physical Properties of Materials by means of financial help from the diamond industry. It was stated in the press that the terms of appointment to this chair required an undertaking by the professor to act as a consultant to the diamond industry, and that he should hand over to the industry any patents arising from his researches. These terms having been brought to the notice of the Council of the Association of University Teachers met with a great volume of protest and an almost unanimous motion of condemnation. ${ }^{41}$

It afterwards appeared that the information as to the terms of this appointment which had been placed before the Council was inaccurate in important particulars, and that the professor's obligations were to be of a voluntary rather than of a mandatory character. Even so, the episode is indicative of the dangers inherent in the present situation in the United Kingdom, and also of the altertness to it which exists among university teachers, who are probably more sensitive to the implications than are the university authorities themselves.

${ }^{80} \mathrm{Dr}$. Coslett puts the figure at no higher than $6 \%$.

${ }^{10}$ Thus, Dr. Coslett says that $25 \%$ of senior research workers receive their stipends direct from industrial sources.

${ }^{1}$ See Minutes of Council Meeting of the Association of University Teachers for December 1962 . 


\section{INTERNAL SAFEgUARDS}

There can be no doubt that the independence of the British universities has been of basic importance in the maintenance of academic freedom as against the state, but the history of religious intolerance at Oxford and Cambridge shows that the autonomy of the institution does not of itself provide a guarantee of such freedom. The question we now have to answer is how far the existing arrangements within the Universities in fact ensure such freedom.

The answer can only be that, while freedom to write, discuss, teach and research does exist in the British universities, it is only to a limited extent maintained by the charters and regulations of the universities; indeed the terms and conditions of appointment and dismissal of their staffs place in the hands of the authorities in some of the universities the means of seriously curtailing academic freedom should they be minded to make use of them. That academic freedom exists in such full measure in the British universities depends much more on tradition, on atmosphere, and on public opinion, than upon legally established rules. Institutionally the British university teacher is less well provided for than his American cousin, who in a number of cases has proved that he has the possibility of relying upon the liberty clauses in the constitution and has enforced his rights in the courts. In practice, however, the position in the United Kingdom has been the more enviable. And this, taking into account that we do not know the doctrine of "tenure" which looms so largely in the American history of academic freedom.

Apart from constitutional doctrines and general rules, however, there is a substantial degree of similarity in the ad hoc situation in the two countries. In both British and American universities the freedom of an individual teacher to write, teach, and research according to the dictates of his conscience depends in the last resort on his being safeguarded from dismissal should his attitude and actions become displeasing to the university authorities. In each case for the individual teacher this depends more than anything else upon the statutes or rules of the university where he works and the terms and conditions of his actual employment.

In England, as in the United States, there are wide variations in the position as between one institution and another. Institutionally, the British university teacher is often without adequate legal protection against dismissal. A full and detailed examination of the various possibilities would be out of place in this article because there is no evidence that use has ever been made by the authorities in any of the British universities of their rights of dismissal. I am speaking of dismissals which could be alleged to have been made in contravention of academic freedom; the position in regard to other dismissals, though satisfactory on the whole, could not be dismissed so lightly. I shall content myself, therefore, with a few observations on some of the more striking points, and with a number of illustrations from cases 
where it has been alleged that academic freedom was betrayed or at any rate endangered.

In the first place, I am not aware that the statutes of any British university specifically guarantee the academic freedom of its members. ${ }^{42}$ The statutes usually require that the Council or other governing authority of the University shall make proper arrangements for teaching, or contain some similar provision; and it is, perhaps, arguable that this requires a degree of academic freedom. There are cases, however, where the determination of studies and teaching is left by the charter entirely at the discretion of the University. ${ }^{43}$ As we have seen already the statutes commonly prohibit religious tests, and interference on religious grounds. More rarely they provide that "no disability shall be imposed on the grounds of political belief,"44 or similar safeguards. Perhaps the nearest approach to a complete safeguard is provided by the Articles of Association of the London School of Economics and Political Science under article twenty-eight, in which it is provided, after a declaration against "religious, political or economic tests" on the lines above mentioned, that no member of the staff shall be "under any disability or disadvantage by reason only of any opinions he may hold or promulgate on any subject whatsoever." ${ }^{25}$

A provision in the statutes that a member of the staff shall only be removed "for good cause" is very common. What is to be regarded as "good cause" is often expressly mentioned in such statutes, but usually in somewhat vague terms such as "misbehavior," perhaps qualified by some such addendum as "rendering him unfit in the opinion of the authority invested with the power of removal to continue in his position." Such statutes may or may not make provision for the formulation of a charge, and for the hearing of the accused before final action is decided against him. ${ }^{46}$ In quite a number of the relevant statutes the right to be dismissed only for good cause is conferred solely upon senior teachers; and junior teachers are left to depend upon the terms of their contracts of employment, under which it is usually provided that the contract may be terminated by means of a short notice. Even when there is a statute providing dismissal for good cause, contracts of employment containing clauses giving the right to remove on a stated period of notice are often also used. Sometimes the statute providing for dismissal for good cause also contains the proviso that the right is subject to the terms of the contract of employment which may effectively destroy the value of the right. In other cases no such cross

"The articles of the London School of Economics referred to below come nearest to it.

${ }^{2}$ A good example is provided by the University of Manchester.

"As, for example, at Birkbeck College in the University of London.

1s The School, which is a constituent college of the University of London is unusual in that it is organized as a company under the Companies Acts, 1948, II \& I2 Geo. 6, ch. 38 .

${ }^{10}$ It could be expected that, even when the statutes do not make provision for proper hearings of charges of misbehavior, the university authorities would see to it that the accused would be given an opportunity to make his case. Unfortunately, universities do not always conduct their affairs in this exemplary way. It is considered that in accordance with the requirements of natural justice which, however vague, is a doctrine accepted by the English courts, a teacher dismissed "for good cause" is, in fact, entitled to be heard in his own defense. Cf. Ridge v. Baldwin, [1963] 2 All E.R. 63 (Ch.); University of Ceylon v. Fernando, [1960] I Weekly L.R. 223 (P.C.). 
reference appears in the statute, and such procedures might well give rise to difficult questions as to the reconcilement of the conflicting powers.

As I have already indicated there is a complete lack of reported decisions on the dismissal of University teachers. ${ }^{47}$ This does not mean that there have not been cases where dismissals were alleged to be wrongful, but that these charges were either withdrawn or a settlement of the case was reached. On the other hand, there are some cases where the terms of appointment are left by the statutes or charter of the institution entirely at the discretion of the governing body. ${ }^{48}$

There does not appear to have been any case where even a colorable argument has been advanced that a dismissal took place which involved a breach of academic freedom. ${ }^{49}$ It may, however, be useful to look at the few incidents in which the matter has, in fact, been discussed on that basis.

The one which attracted most attention was that of Mr. Andrew Rothstein, a Communist, who was, in 1946, appointed to the staff of the School of Slavonic Studies in the University of London for a period of one year in connection with a project for teaching social and economic subjects at the School. This appointment was later renewed, for a further experimental period of three years. At the time of his reappointment it was made clear to Mr. Rothstein that his post might not be renewed; and he was not put in the superannuation scheme, which was an indication that his position was not regarded as permanent.

Before the end of the three years Mr. Rothstein was informed that no further renewal would be made. He took the view that if he had not been a Communist, this would not have occurred, so that in his view there had been an infringement of academic freedom; and his local branch of the Association of University Teachers felt that the matter ought to be inquired into and submitted it to the Central Executive Committee of the Association for action. At the same time a substantial body of Mr. Rothstein's students at the School petitioned the authorities there on his behalf, testifying to the fairness and objectivity of his lectures. After careful inquiry and discussion with the authorities at the School the Central Executive of the Association was satisfied that the decision not to renew Mr. Rothstein's appointment had been taken because, in the light of his published work, his scholarship was adjudged not to be of adequate quality and that his political faith had not been taken into account by the School in reaching this decision. Mr. Rothstein afterwards brought his case before the Central Council of the Association which, after hearing him and his supporters, passed a resolution stating that no evidence had been obtained that

${ }^{47}$ The case of Orr $v$. University of Tasmania, 228/1956 (on appeal (dismissed) High Court of Australia; Tasmanian Registry 7/1956), an Australian case, attracted much attention in England at the time; a professor had been dismissed for misbehavior and sued for wrongful dismissal-unsuccessfully, however. mine."

${ }^{8} \mathrm{Cf}$. School of Oriental and African Studies in London: "such terms and conditions as they deter-

to The author has been closely connected with the work of the Association of University Teachers for some twenty-five years, during the greater part of which he acted as honorary legal adviser. Not only is he unaware of any such case, but there is no tradition of such a case within the Association. 
discrimination had been exercised against him on political grounds. Mr. Rothstein's supporters afterwards attempted to persuade the Convocation of the University of London to endorse his case, but this attempt failed also. It will be apparent that the Rothstein case was well canvassed, and to a considerable degree in public, over a substantial period of time, but that no real evidence was ever adduced to show that there had been an infringement of academic freedom.

The next case for discussion, that of Dr. J. H. Cort, however, possibly did involve: such an infringement, though, unfortunately, the essential facts are obscure, and sincehe was not a British citizen and did not hold a British passport, it could not furnish. an important precedent. Dr. Cort, an American citizen, was in I953 appointed to a lectureship at Birmingham University. Aliens can only reside in Great Britain if permitted to do so by the Home Secretary. Dr. Cort who had already at the time of his. appointment had permits for more than one period of residence then applied for the renewal of his existing permit for an indefinite period. He was officially informed that he could stay only until June 30, I954, a decision which was never withdrawn. No reason for this action by the Home Office was ever given. However, it wasstrongly suspected that the cause was Dr. Cort's earlier political history, because, while a student at Yale, he had been a member of a Communist organization. Attempts. were made, both by the Birmingham branch of the Association of University Teachers and in the House of Commons, to persuade the Home Secretary to renew the permit, or to state a case for not doing so, and there was considerable public discussion of the case in some of the newspapers; but all to no avail. Since the: Home Secretary cannot legally be required to give the reasons for his decisions in such cases, and in practice does not do so, there is no evidence as to what the case against Dr. Cort was, if any. Clearly, however, it was essentially different from that of Mr. Rothstein, in that the action that was taken was that of the government not of the academic authority, and was only made possible by the fact that he was not a British citizen. ${ }^{50}$

These two cases, which are the nearest I have been able to find in which it could plausibly be argued that academic freedom had been infringed in England, ${ }^{51}$ show, I

${ }^{\circ 0}$ In 196I there was a similar case in Australia where the University of Adelaide had appointed $a$ Mr. Y. S. Brenner to a lectureship. $\mathrm{He}$ is an Israeli who in early life was a member of the Stern gang, a terrorist organization which had played a prominent part in the struggle of Zionism. However, he had for several years been a research student in London University where he had a good record. His political past was known to the authorities of the University who very properly considered that it was irrelevant to the question of his appointment. The Government of Australia, however, refused him a residence permit, without giving any reason for their decision, an attitude which it maintained, despite considerable pressure in Parliament. Later on, over in Australia also, a well-known English anthropologist, Professor Gluckman, who had been appointed to a post at the Australian National University at Canberra, in order that he might do research work in New Guinea, was refused a permit to visit the island, which is under the jurisdiction of the Commonwealth of Australia.

${ }_{51}$ Two further cases should perhaps be referred to, though they hardly qualify for more than a footnote. In 1939 among the members of the Welsh National Party who burned down some buildings at a Royal Air Force airfield, was a young lecturer at University College, Swansea. The participants in this exploit were convicted of arson and sentenced to imprisonment, a serious felony. It is not surprising that the young man was deprived of his lectureship; nor does he appear to have claimed that he had 
think, that so far as direct interference goes British academic staffs have very little to complain of.

\section{VIII}

\section{Extramural Activities of Staff}

The question whether academic freedom relates only to discussion, teaching, and research within a University, or protects the participation of the teacher in political or other activities outside his professional work is familiar in the United States and has from time to time been debated in England, though the material which can be profitably offered here is exiguous, and is more concerned with the position of teachers in schools than with teachers in universities. ${ }^{62}$

The matter has been mainly discussed among university teachers in relation to three points: (I) putting up for Parliament; (2) general political activity; and (3) activities of a general social character. Under these last two heads there have been cases which have given rise to adverse comment-particularly, perhaps, in connection with writing for newspapers or association with political groups advocating extremist policies. It cannot be said that there is any accepted consensus of opinion in the British universities with regard to activities of these kinds, and the following comments are offered with some diffidence. ${ }^{53}$

Quite a number of university teachers offer themselves for Parliamentary election, and they are representative of all the political parties. It is generally accepted that they are quite free to do so, provided they do not allow this political activity to interfere with their professional work. Most of the universities are prepared to give a leave of absence during the period of the elections to a member of their staff who stands as a candidate. Should he be elected, the question will arise whether he must resign his appointment. There seems to be no accepted practice about this. ${ }^{54}$

been unfairly treated, though the offense was undoubtedly political in the sense that it was mainly directed to further the course of Welsh nationalism. Some time after completing his sentence, he was appointed to a post in another university college. (I am indebted to a colleague for reminding me of this case which I have not had time to particularize in greater detail.) Reference may also be made to the case of Alan Nunn May, a lecturer in the University of London who, in 1946, was sentenced to ten years' imprisonment under the Official Secrets Act, I9II, I \& 2 GEo. 5, ch. 28 , for betraying information relating to nuclear fission. Alan Nunn May also was dismissed from his lectureship; but his colleagues in King's College, London, were satisfied that he had acted from genuine motives and made several attempts to persuade the Home Secretary to reduce his sentence, but without success.

${ }^{52}$ It will be referred to more fully in the section on Academic Freedom in Schools, at the end of this article.

${ }^{53}$ In so far as I am in a position to discuss this problem in a concrete manner, I do so by reference to discussions within the London School of Economics and Political Science in the University of London which took place in the I930's. As, however, this material is confined to a single institution, and I am unable to say how typical it is of the position elsewhere, I shall confine my observations to a series of footnotes.

s4 The only actual rule relating to the matters of which I am aware is laid down by the Court of Governors of the London School of Economics and Political Science in 1932. This was formulated after full discussion with the teaching staff represented by the Professional Council, and was as follows: ". . . that the position of members of the regular staff (whether full time or part-time) becoming Members of the House of Commons, should be considered after report from the Appointments Committec, in each case on its merits, subject to the principle that, as a general rule, membership of the House of 
In earlier times, when standing for Parliament was, in practice, confined to fellows of Oxford and Cambridge Colleges, it was not unusual for a member of Parliament to retain his fellowship. In recent times, life in the universities has become much less leisurely, and membership of the House of Commons would now generally be regarded as incompatible with the holding of a full-time teaching post in a university, ${ }^{\text {55 }}$ so that if he were called upon to resign such post it would hardly be regarded as an infringement of academic freedom.

With regard to the second and third types of activity there is a strongly-felt view that they ought to be carried on with due regard to the extra special position of a citizen who is also a university teacher and this view is, no doubt, just as prevalent among university teachers as among responsible members of the general community. ${ }^{58}$

There will be, and indeed have been, rather differing views as to the conduct which is compatible with this widely-held standard. To the governing body of an institution which, notwithstanding liberal government grants-in-aid, is still to a substantial extent dependent for research, and in one way or another, on gifts from business organizations and charitable trusts endowed by wealthy individuals, unorthodox political activities, even if mild in character, may appear damaging; and they will have an incentive to attempt to curb them. This could be done in a number of ways-the most obvious of which are delaying or refusing promotion, or even bringing the employment to an end. If such measures were in fact taken there would clearly be a grave interference with the teacher's liberty of action, and in most, probably all, British universities this would be regarded as a blow to academic freedom. I have never, however, seen any evidence which suggests that this is in fact an actual danger. ${ }^{57}$

Commons is inconsistent with the tenure of a full time post at the school." It is interesting to note that this problem became one of practical importance at the London School of Economics because two senior members of staff, Messrs. Dalton and Lees-Smith, had not only been elected Members of Parliament, but had also been appointed Ministers of the Crown. With true British regard for vested interests, the resolution of the Governors was not regarded as applying to them.

${ }^{B E}$ Membership of the House of Lords, even if active, would, however, hardly be regarded in the same light, as service there is much less strenuous in character.

Eo Another clause of the London School resolution above referred to provides that "while members of the staff of the School of Economics ... . should be free from regulation or censure by the Governors of the School in respect of their writings or public speeches, they should regard it as a personal duty to preserve in such writings or speeches a proper regard for the reputation of the School as an academic centre of scientific teaching and research." And see the similar resolution of the Council of the Association of University Teachers at its December 1934 meeting, the period of the Hitler expulsions.

${ }^{57}$ It may well be that from time to time Vice-Chancellors, or Principals, or heads of departments have given friendly advice about, or, indeed, attempted to dissuade one or another member of their staffs from, active engagement in political or other work which they considered inimical to the prosperity of their institutions. Indeed, the late Professor Laski, who was well known as a trenchant advocate of socialism, both on the platform and in the press, once told me that the Director of the London School had indicated to him that in his opinion his (Laski's) activities were not in the best interest of the School. Professor Laski did not complain that any steps had been taken to require him to accept the advice implicit in this statement, and it can hardly, I think, be contended that the Director (at that time, Sir William Beveridge) had done anything wrong or anything which amounted to an infraction of academic freedom, although many would consider that he went as far as he could properly go. 
IX

\section{Students and Academic Freedom}

It is not necessary to deal at length with the specific problem of university students in relation to academic freedom in England. What has been said above about tests on admission and otherwise applies to them particularly. They are, of course, subjected to university discipline the rigidity of which varies to some extent from one institution to another. ${ }^{58}$ Obligations in regard to studies, attendance at lectures, keeping terms and in other similar respects are general, though again they vary a great deal from one institution to another, and are so obviously necessary as not to call for comment. Student activities in connection with politics are not in any way fettered provided they do not infringe disciplinary requirements. Thus Communist Parties, and indeed Fascist Parties, may be, and are, formed; and no penalization follows from membership in such unpopular minority groups. ${ }^{60}$

One aspect of the student's position which has received all too little attention is that of his possible expulsion from the University. This occurs not infrequently for disciplinary reasons, but his right to have such a decision reviewed is far from clear. He is presumably entitled to receive "natural justice" at the hands of the university authority; but unless he can show a breach of this right, it is unlikely that he would be able to persuade a court to intervene on his behalf. Moreover, being in statu pupilari, he would apparently not be in the same position as the members of the teaching staff in respect of procedural rights in making his casc. ${ }^{00}$ I have no evidence that any student has in recent times been expelled from a British University on grounds which amounted to a violation of academic freedom. In some cases if that were to happen, he would as a member of the University be entitled to the same rights of protection as the members of the academic staff.

\section{X}

\section{Academic Freedom in the Schools}

Finally something must be said about academic freedom in the general school system, though it is not a subject which I have any competence to discuss. Broadly

${ }^{\text {ss }}$ At Oxford and Cambridge the statutes confer extensive disciplinary powers over students to officials known as proctors, who have from time to time made use of them to censor student publications, and to fetter student activities, particularly in regard to matters of sex. Opinions differ a good deal as to how far such interferences with the liberty of students are to be regarded as infringements of academic freedom.

${ }^{59}$ Thus, at the Cambridge Union, a Mr. Pollit, a Communist, and the son of a deceased Chairman of the British Communist Party, was recently elected President-certainly as a tribute to his personality and oratorical ability, rather than in support of the political faith of the Communist party, the membership of which is very small.

${ }^{\circ 0}$ This seems to be the necessary inference to be drawn from the decision of the Privy Council in the case of the expelled Ceylonese student Fernando; see University of Ceylon v. Fernando, [1960] Weekly L. R. 223 (P.C.). 
speaking, schools in the United Kingdom are either state schools, voluntary schools, ${ }^{61}$ or independent schools, for unlike the case of the universities there is no legal obstacle which prevents a private citizen or organization from running a school. The independent schools are often called private schools and these are very numerous; but when they achieve a certain size and dignity they usually become "public schools." 22 Many of them are maintained by religious organizations; thus, the Roman Catholic Church has for many years provided both primary schools and schools of higher education. In particular the Church of England was, until about the beginning of the present century, responsible for providing most of the primary education in the country. Its schools are usually called "Church schools." institutions of secondary education, the so-called "public schools" Anglican foundations.

The question of academic freedom in the schools has in the United Kingdom centered much more round conflicts of religion than conflicts of politics, though for long there was a fairly close connection between the Liberal Party and the nonconformist denominations ${ }^{65}$ which on the whole, unlike the Roman Catholics, made no attempt to establish their own educational system but concentrated on preventing the state or state-aided system from being used by the Anglicans for the education of their children in Church of England doctrines. "Conscience clauses" were inserted in "Education Acts," and for many years the problem of educating nonconformist children in schools where religious instruction was based on the tenets of the established Anglican Church was a burning one. However, a compromise solution based upon the teaching of an "agreed syllabus" was eventually worked out and is embodied in the Education Act, 1944. This normally provides for religious worship and instruction of a non-denominational Christian character which, since almost all the children are nominally Christian, does not give rise to much hostile feeling, especially as there are safeguards under which nonconformist parents may withdraw their children. Moreover, denominational schools may now be aided and supported under special agreements with local educational authorities, so that in large measure primary education of a denominational character is now heavily financed by the general taxpayer. The most distinctive, and strongly criticized, feature of the Education Act, I944, is that for the first time it gave the blessing of the state to Christian worship and instruction in the schools. This is logically a serious infringement of

\footnotetext{
on The expression voluntary school has acquired a technical significance. It means a school which was originally founded outside the state system, usually by a religious body, but has become state aided under the provisions of the Education Acts.

${ }^{03}$ As to these, see infra note 64 . The expression "independent school" is used in the Education Act r944, $7 \& 8$ Gzo. 6 , ch. 31 , to describe schools which do not receive state assistance.

os A description which the Roman Church might well claim to share.

ot 'Technically there are only seven "public schools" under the Public Schools Act, I868, 31 \& 32 VICT. c. II7, \$3. But schools represented on the Headmasters' Conference are commonly described as public schools. They are for the most part large boarding schools.

${ }^{O 5}$ It must be borne in mind that in England a "nonconformist" is a Protestant who does not conform to the Creed of the Church of England.
} 
religious and academic freedom; but its practical consequences have not given cause for alarm, though some serious students of affairs feel that liberty is being insidiously and seriously undermined. In the state secondary schools the rules are much more strongly set against denominational worship and instruction; but the Christian religion continues to receive the support and authority of the State.

It is, of course, only within the area where it provides financial support and assistance that Parliament controls religious worship and instruction in the schools. In all the schools which remain private institutions the proprietors may make what arrangements they like.66 We have already seen that many of the great "public schools" are Anglican foundations. Here on the whole both worship and instruction sit lightly on the scholars, and there is little or no pressure in the direction of conformism. The Roman Church has built up its own system of public schools in which the educational standards are high, and the pattern of conformity is believed to be much more rigid. There are few public schools run by nonconformists, except for a comparatively small group belonging to the Society of Friends. In all these schools the general pattern follows that of the denomination which runs the school, but discipline is not strict.

In politics questions of academic freedom have seldom arisen in the schools. In the private schools the proprietors could no doubt insure that only teachers who conformed to their own political views were appointed; there is very little evidence that they ever do so. In the secondary school system local education authorities are responsible for the staffing of the Schools. With one exception, the County of Middlesex, no local education authority has ever attempted to ensure that only politically orthodox teachers are employed in its schools; and this policy was reversed after a few years when the political complexion of the Council changed. ${ }^{67}$ This appears to be the one flagrant infringement of

${ }^{60}$ This is not to say that the private or independent schools go entirely without supervision. They have to be registered and the Minister of Education is given considerable powers under $\$ \$ 7-73$ of the Education Act, I944, $7 \& 8$ GEo. 6 , c. $3 I$, to insist on the maintenance of standards both in regard to school buildings and efficiency of instruction.

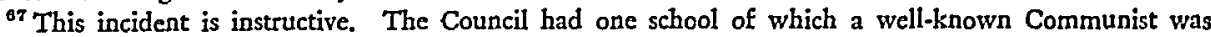
headmaster. Although he had the reputation of being a good teacher and an excellent headmaster, he was an active politician and his name appeared fairly frequently in the newspapers. When a further nomination of a Communist to a headmastership to a primary school in Middlesex was made by the Education Committee, the Council, in June, 1950, refused to confirm the appointment, and in October of the same year passed a general resolution excluding Communists and Fascists from becoming headmasters or occupying posts in Teacher Training Colleges within its jurisdiction. Both these actions were opposed by the National Union of Teachers, and other teachers' organizations, and also by the Minister of Education (even when this post was occupied after 195 I by a Conservative). No cvidence was ever forthcoming that any Communist teacher employed by the authority had abused his trust; but the Council maintained its decisions until after an election in 1958, when its political majority changed. Three further points may be noted by way of addenda to the Middlesex case: (I) Mr. Colin Jordan, the leader of one of the two British Fascist Parties, was a schoolmaster at Coventry employed by a socialist Local Education Authority until his conviction in 1962 of an offense under the Public Order Act, 2936 , I EDw. 8 and I Geo. 6, c. 6. (2) In a letter appearing in the Times Newspaper of Mar:h 7, 1957, a member of an interviewing board for the appointment of schoolmasters complained that th: Chairman of the Board had stopped her when she asked a candidate whether he was a Communist on the ground that his political views were irrelevant. (3) An attempt was made some years ago by the Durham 
academic freedom which has occurred in the United Kingdom in connection with the school system, at any rate in recent times. It is fair to say that it was taken by a subordinate authority against the advice of its political leadership, and was pretty well unanimously deplored in the teaching profession. It should, perhaps, also be pointed out that the Middlesex County Council did not go beyond a refusal to appoint. There appears to be no case where a teacher has been dismissed on political grounds. ${ }^{88}$

Perhaps, in conclusion, it should be made clear that the allocation of responsibility for manning the state school system is fairly closely defined as between the central and local authorities by the Education Act, 1944. The Middlesex case happened to fall within that area which the Act entrusts to the local authority. Generally speaking, however, the Minister's powers are much wider than those of the local authorities, over which he is also given considerable powers of control. His powers, however, are for the most part fairly closely defined by the Education Act, 1944, and could only be used very indirectly and very sparingly in such a way as to interfere with academic freedom. Moreover, there is perhaps no minister whose work is under more constant and searching examination by the Opposition in Parliament, so that the chances of any substantial abuse of his position may be regarded as slight.

County Education Committec to impose trade union membership on their teachers, which, however, failed.

${ }^{08}$ It is far from clear that the Court would have power to intervene in such a case, since if an authority acts bona fide the Court will not inquire into the adequacy of its reasons. Price v. Rhondda Urban Council, [1923] 2 Ch. 372. 


\section{The \\ DUKE LAW JOURNAL}

A law review edited by students of Duke University School of Law and devoted to a discussion of legal topics of current interest.

VoluMe I963, No. 3 (SUMMeR) INCLudes:

Articles:

Dedication of the New Duke Law School Building by Earl Warren

Psychiatry, Criminal Law, and the Role of the Psychiatrist by Ralph Slovenko

Federal Tax Symposium:

Insanity as a Defense to the Civil Fraud Penalty by Kenneth G. Anderson

The Choate Lien Doctrine by James D. Burroughs

Applicability of the Fourth Amendment in Civil Cases by Louis 7. DeReuil

Taxability of Scholarships and Fellowship Grants by Paul J. Weiss, Jr.

\section{Comments:}

Charitable Annuities: Cost and Capital Gain in Light of 1962 Revenue Rulings

International Joint Venture Corporations: Drafting of Control Arrangements

Address Subscriptions and Inquiries to

The Managing Editor

DUKE LAW JOURNAL

DURE UNIVERSITY School of LAW

Durham, N. C. 